\title{
THE EFFECT OF ECONOMIC GROWTH AND DEMOGRAPHIC CONDITION ON CRIMINALITY IN EAST JAVA PROVINCE
}

\author{
Fani Novi Hariyanti ${ }^{a}$ \\ Rafael Purtomo S \\ Regina Niken Wilantari \\ Ilmu Ekonomi dan Studi Pembangunan, Fakultas Ekonomi dan Bisnis \\ Universitas Jember \\ Email: faninovi.01@gmail.com
}

ARTICLE HISTORY

Received:

29 July 2020

Revised

19 November 2020

Accepted:

05 January 2021

Online available:

06 May 2021

Keywords:

Economic growth,

Criminality,

Population density, Number of poor people.

\begin{abstract}
Introduction: This study aims to determine how much the effect of economic growth and demographic conditions on the crime rate in East Java Province. This study is using secondary data for 6 years from 20132018.

Methods: The data analysis method used in this study is panel data regression analysis method with the Fixed Effect Model (FEM) approach. The dependent variable used in this study is the crime rate, while the independent variables are economic and demographic growth, which includes population density and the number of poor people.

Results: Based on the results of this study, it can be concluded that economic growth has a positive but insignificant relationship to the crime rate in East Java Province. Population density has a positive and significant relationship to the crime rate in East Java Province. Meanwhile, the number of poor people has a negative and significant relationship with the crime rate in East Java Province. The results of the study also show that economic growth, population density and the number of poor people have an effect and significant relationship on the crime rate in East Java Province.

Conclusion and suggestion: This needs an equitable distribution of income and empowerment of human resources through improving educational facilities and infrastructure as well as skills so that productivity and community income increase. In addition, it is necessary to have equitable development and the provision of employment opportunities in each region so that population density is not concentrated in one or several areas.
\end{abstract}




\section{INTRODUCTION}

Indonesia is an archipelago country that has different wealth, this comes in terms of natural resources, human resources, capital resources, culture, facilities and infrastructure. The existence of these differences causes the ability of each region in Indonesia to promote economic growth and the development process will also be different. That kind of condition causing the rich areas getting richer and poor areas getting poorer. This has led to the emergence of development inequality between regions and the widespread of poverty problem. The widespread problem of poverty triggers people to commit criminal acts due to the difficulty of obtaining income from legal work. The high crime rate in an area illustrates the increasing risk of the population becoming victims of criminal acts.

Based on an economic analysis of crime that has been carried out by Becker (1968) through his book entitled Crime and Punishment: An Economic Approach. Becker argued that a rational individual will engage in criminal activity if the expected net benefits (utility) from the criminal activity exceed the utility he/she gets from activities that do not violate the rules or laws. The damage or loss arising from this criminal activity will certainly affect the welfare of individuals and society as a whole. This is in line with Cornish and Clarke's theory of rational choice in Hagan (2013: 141) that the perpetrator will weigh the opportunities, costs and benefits of the criminal activities he/she commits. However, in the theory of rational choice, individuals are not considered completely rational in making decisions, but they do weigh the costs and benefits they will receive from these activities.

Meanwhile, Herbert A. Simon's view in Firmansyah et al. (2013) stated that the rationality of individual on making decisions is limited to two things, namely information and cognitive abilities (habits, values, knowledge, references, etc.). Simon also said that it is very difficult to make fully rational decisions because of the limited resources available to process information. The result of this decision making is a satisficing choice, namely that the decision taken is not an optimal decision.

Empirically, Mulok et al., (2016) found a positive effect between the crime rate on economic growth both in the long and short term in Malaysia. Another study conducted by Adekoya dan Razak (2017) also found that in the short term the crime rate as reflected in the prosecution and punishment variables has a positive and significant effect on economic growth in Nigeria.

However, a study conducted by Ahmad et al., (2014) showed different results. This study explained that there is a negative relationship both in the short and long term between the crime rate and economic growth in Pakistan. This is in line with the results of study conducted by Detotto and Otranto (2010). Detotto and Otranto (2010) found a negative relationship between criminal activity and the performance of the Italian 
economy as a whole. He also revealed that criminal activity is an obstacle to investment both at home and abroad, and can reduce the competitiveness among companies, and causing a resource shifting which in turn creates uncertainty and inefficiency. Another study conducted by Peri (2004) also found that the number of crimes has a negative effect on economic growth which is reflected in the decline in per capita income and employment growth in Italy.

Based on the Criminal Statistics released by the Central Statistics Agency, during 2015-2017 the number of criminal acts in Indonesia tended to fluctuate. As shown in Figure 1.1 in 2015 alone, the number of reported criminal cases in Indonesia (total crime) was 352,936 cases, then increased to 357,197 cases in 2016 and decreased in 2017 to 336,652 cases.

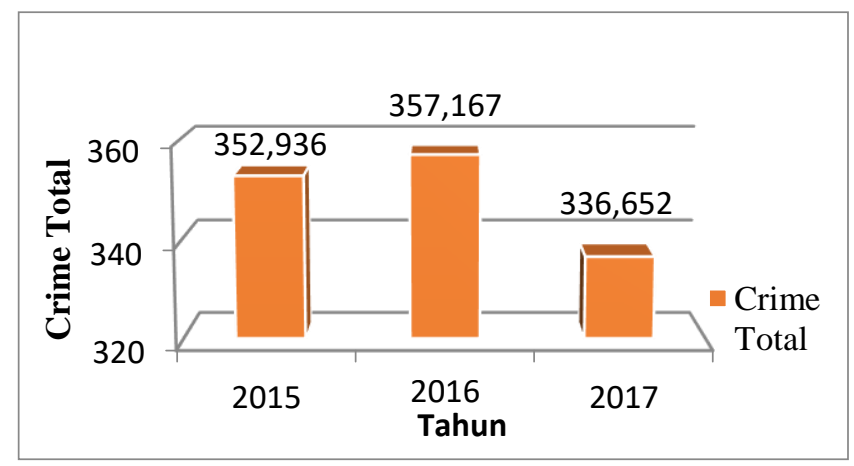

Figure 1.

Graph of Reported Number of Crime Cases (Total Crime) in Indonesia.

Source: CBS (Central Bureau of Statistics), processed data

Judging from the large number of criminal cases that occurred in Indonesia, East Java Province is the province with the second highest crime rate after Metro Jaya. This is supported by the condition of East Java as one of the provinces with the second largest population in Indonesia after West Java. So it does not rule out the high population in East Java which encourages people to commit crimes.

When it viewed from the structure of the economy, the contribution of the Gross Regional Domestic Product (GRDP) per capita given to East Java continues to experience a significant increase every year. The amount of contribution made by the Province of East Java to the national economy reached $14.67 \%$ (CBS, 2019). However, the high of GRDP figure does not fully reflect the level of welfare in an area (Prakoso, 2016). This can be seen in Figure 1.2 which shows that the increase of GRDP per capita in East Java is not followed by a decrease in crime, meaning that when the GRDP per capita in East Java increased, it is followed by an increase of crime in East Java. 


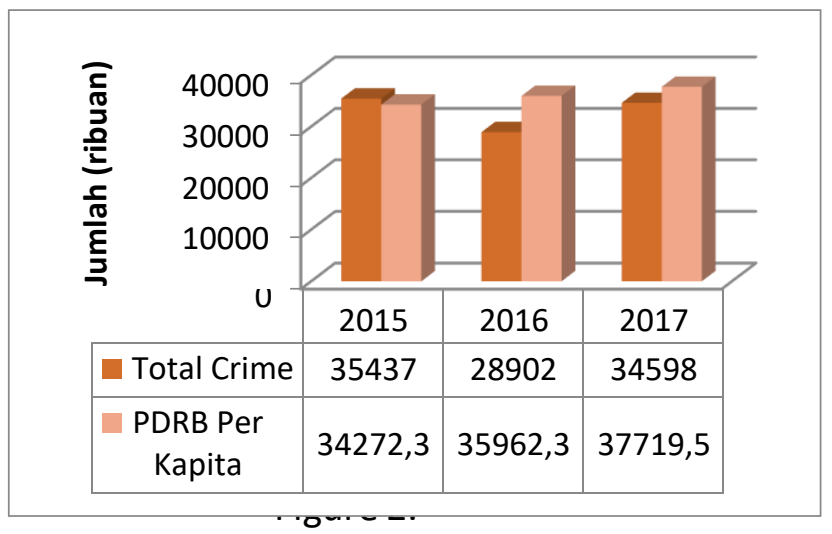

Graph of the Number of Crime Cases (Crime Total) and GRDP Per Capita in East Java

Source: CBS (Central Bureau of Statistics), processed data

The high crime rate will indirectly reduce the quality of economic growth in a region. The increase in the crime rate will certainly have a negative effect on the economic growth of a region by increasing the variable costs of production (Kusuma et al., 2019). An increase in costs will later have an effect on the selling price and the number of goods or services produced and will reduce the GRDP received by the region. The high crime rate is also considered to provide a negative perspective for investors who will invest in the concerned region.

\section{LITERATURE REVIEW}

Criminology according to Ndach in Abdulsyani (1987) is the science of the manifestations of the causes and consequences of crime. The ideas put forward by Cesare Beccaria and Jeremy Bentham in the classical school consider that criminal behavior originates from the basic nature of humans as hedonistic as well as rational creatures. Hedonism means that humans tend to act in self-interest. Meanwhile, rational is able to calculate the benefit-cost of the action, thus a person always calculates the profit and loss of their each act, including if he/she commits a criminal activity. The foundation of this classical school is that individuals are born with free will, where every human being has the freedom to choose actions that can give happiness and avoid actions that will give suffering. In addition, Jeremy Bentham saw a new principle, namely ultitarianism, which states that a person must always act in a way that produces the greatest possible ratio.

The Neo-classical school also has the same base of thought as the classical school, namely believing in human freedom in their wills. Criminals in neo-classical theory are seen as actors who are rational and responsible for their actions or free will. Neoclassical assumes that every individual on making decisions always behaves rationally, 
taking into account the benefit-cost of each decision making in order to maximize the satisfaction (utility maximalization). In this context, humans are considered as homo economics (economic actors), which means that humans will continue behaving in the context of obtaining rent seeking, working at zero transaction costs without including an institutional role in it (Landa dan Wang, 2002).

According to Gary S. Becker (1968) through his book entitled Crime and Punishment: An Economic Approach argued that rational individuals will carry out criminal activities if the expected net benefits (utility) from these criminal activities exceed the utiliy that he/she gets from the activity that doesn't break any rules or laws. Considering the level of profit and costs incurred can be used to assess how satisfied they are in committing a crime compared to non-criminal acts. Becsi (1999) revealed that in the criminal economy model there are four actors who are assumed to make rational decisions, namely criminals, domestics, non-criminals and the government.

Meanwhile, according to the concept developed by Herbert A. Simon in Firmansyah et al. (2013) said that individual rationality is limited (Bounded Rationality). The rationality of individual decisions on making decisions is limited to two things, namely information and cognitive abilities (habits, values, knowledge, references, etc.). Simon also said that it is very difficult to make fully rational decisions because of the limited resources available to process the information. The result of this decision making is a satisficing choice, namely that the decision taken is not an optimal decision.

The decision maker will choose to use a satisfactory alternative instead of an optimal alternative. When the decision maker considers that the alternative chosen is satisfying, the search process will be terminated. The aspiration level will increase when the search process finds new alternatives and will decrease when the search process is not productive. The Bounded Rationality Model is a simple model that is able to make the practice of a person's decision-making process more realistic.

\section{RESEARCH METHODS}

The type of data used in this study is panel data (pooled data), which is a combination of time series (2013-2018) and cross section according to districts/ cities in the Tapal Kuda area. Sources of data in this study were obtained from the Central Bureau of Statistics (CBS), and various sites related to study. The Tapal Kuda area consists of 6 districts and 1 city covering Lumajang, Jember, Banyuwangi, Bondowoso, Situbondo, Probolinggo, and Probolinggo city. In terms of geography, geology, climate and vegetation, the majority of the inhabitants of the Tapal Kuda area are inhabited by Madurese and Javanese ethnicities (Astutik, 2017). The Tapal Kuda area is also one of the areas with the highest number of crime contributors in East Java after Surabaya City. 
From these reasons, the researcher chooses the Tapal Kuda area as a sample in the study. This study uses panel regression (pooled data) using the E-views 9 software program.

RESULT AND ANALYSIS

Table 1.

Estimation Results of Panel Data Regression with Fixed Effect Model

\begin{tabular}{ccccc}
\hline Variabel & Coeffient & Std. Error & t-Statistic & Prob. \\
\hline C & 1659.068 & 520.2530 & 3.188963 & 0.0032 \\
X $_{1}$ & 38.28750 & 33.19469 & 1.153422 & 0.2573 \\
$\mathrm{X}_{2}$ & 1.410079 & 0.412453 & 3.418762 & 0.0017 \\
$\mathrm{X}_{3}$ & -19.18028 & 0.983023 & -19.51153 & 0.0000 \\
R-squared & 0.819011 & & & \\
Adjusted R-squared & 0.768108 & & & \\
\hline
\end{tabular}

\section{The Effect of Economic Growth on the Crime Rate}

Based on the estimation results in Table 1, it shows that economic growth has a positive and insignificant relationship with the crime rate in East Java Province, meaning that when there is an increase in economic growth in East Java Province, it will not affect the number of crime rates in East Java Province and vice versa. This result is not in accordance with the initial hypothesis that economic growth has a negative effect on the crime rate in East Java Province, when the higher the economic growth, the lower the crime rate.

Based on the East Java ADHK GRDP per capita data in attachment 7, it shows that the value of GRDP during the 2014-2018 period has increased significantly every year. This illustrates the welfare of the people of East Java due to the GRDP is an indicator of economic growth. However, the high economic growth of a region does not fully reflect the level of welfare and level of development in the region. This occurs due to the effect of other factors such as uneven distribution of income, different patterns of public expenditure, age structure of the population and economic development which not only increases people's income but also has to reduce the number of unemployment. Therefore, the high economic growth of a region has not been able to become a measure of the public welfare, because the increase in economic growth indirectly has led to large social costs, one of which is in the form of higher crime.

An individual will commit a criminal act if the benefits obtained exceed the costs arising from the crime (the opportunity to be caught and the costs incurred if caught), it 
means that the criminal act provides an incentive response in the form of net benefits from the crime he/she committed. According to the neo-classical theory, criminals are seen as rational actors and responsible for their actions or free will because their actions based on maximizing utility (satisfaction) by taking into account the benefit-costs on making decision. In this context, humans are considered as homo economics (economic actors), which means that humans will continue to behave in order to obtain rent seeking, working at zero transaction costs without including an institutional role in it (Landa and Wang, 2002). Income per capita can have a positive effect on the crime rate because of the increasing wealth of some people will increase the potential income from crime. So that the level of public welfare will experience a decrease in income due to the increase inequality of income distribution (Laudrisen et al , 2013).

The result of this study is in line with the research conducted by Pavlo (2011) who found that economic growth has a positive and insignificant effect on the crime rate in Ukraine. This is because of the development of the Ukrainian economy has not led to an increase in the living standard of its inhabitants. The efficiency of the police is one of the most important instruments for combating criminal activity and the functioning improvement of the police can lead to a significant reduction in illegal activity. Another factor that greatly affects the crime rate in Ukraine is the level of education which has a negative effect on the crime rate. Therefore, it can be concluded that the criminal activity of Ukraine is mostly a cultural and psychological phenomenon. On the other hand, drug-related crimes are concentrated in areas that are more economically developed.

According to Beki et al (1999) the more income is spent, the less time is spent indoors so that it will increase outdoor activities which may increase involvement with criminal activities. Meanwhile, according to Khan et al (2015) the positive relationship between economic growth and the crime rate only applies in a short period of time. In the long run, economic growth can be negative, which means that if economic growth in a region increases, so it will reduce the crime rate in that region. Bender and Theodossiou (2016) said that high economic growth will affect a person to carry out criminal activities, but it can only affect certain types of crime, such as property theft, robbery, deprivation, and mugging. This occurs as a result of income inequality among regions. The higher the socio-economic gap, the higher the crime rate in the region.

\section{The Effect of Population Density on the Crime Rate}

Based on the study findings from the estimation results in Table 1, it shows that population density has a positive pattern and significant relationship to the crime rate in

East Java Province. This means that when the population density in East Java Province 
increases, the crime rate in East Java Province will also increase. This study is in accordance with the initial hypothesis that population density has a positive effect on the crime rate in East Java Province.

Similar research results were found by Prakoso (2016), he found that population density variable with high levels of income inequality has a positive and significant relationship to the crime rate in Indonesia. This is caused by the high population density has a high enough potential for criminal acts as a result of the large number of people living in an area. In line with the study conducted by Prakoso, Lispani et al., (2018) also found that population density has a positive and significant relationship to the crime rate in East Java Province. Similar to study conducted by Dona dan Setiawan (2015), population density has a positive and significant relationship to the crime rate in East Java Province. The very high population density causes the potential for crime to be higher.

Based on CBS data, it shows that during the last 4 years $(2015$ - 2018) the total population density of East Java Province has always increased. In 2015, the population density of East Java reached 809 people per km2, then continued to increase until 2018, reaching 826 people per $\mathrm{km} 2$. High population density has the potential to increase crime in that region. This is in line with Becker's (1968) rational choice theory, which stated that crime is more prevalent in areas with high population density because of the return incentive from criminal activity is greater and the cost of being caught is lower.

Increased crime in densely populated areas often occurs in areas which have characters similar with urban areas, one of which is due to the problem of movement (mobility) and high population movement (migration) which results in the decreasing of the capacity in living areas. The increase of population in Malthus's theory will have an effect on the use of land. This is due to the fact that land as a carrying capacity for the environment is not able to meet the needs of the growing population, which causes a decrease in output. The reduced output is what will reduce the GDP per capita of each province so that the absorption of labor will decrease. The decrease in labor absorption causes high unemployment rates, especially in provinces with high levels of income inequality, so it is suspected that these unemployed people who are likely to commit crimes (Anata, 2013). As a result of difficulty to find legal work and narrow job opportunities as well as the lack of education and skills possessed by job seekers. Fleisher and Erlich in Pavlo (2011) said that the majority of criminals come from unemployed people.

\section{The Effect of the Number of Poor People on the Crime Rate}


Based on the study findings from the estimation results in Table 1, it shows that the number of poor people has a negative and significant relationship to the crime rate in East Java Province. This means when the number of poor people in East Java Province increases, the crime rate in East Java Province decreases. The result of this study is not in accordance with the initial hypothesis that the number of poor people has a positive effect on the crime rate in East Java Province, where the number of poor people increases, the crime rate will also increase.

The result indicates that areas which have high crime rates occur in areas with a low percentage of poor people. This fact unlike what happened in other regions in general, which is relatively in accordance with the existing theory that high poverty will be followed by high crime. This can be seen in 2015, the City of Surabaya as the city with the highest crime rate in East Java, namely 6,650 cases with a poor population of 164.72 thousand people. Meanwhile, Malang Regency is a district with the highest number of poor people in East Java, namely 292.87 thousand people has a number of criminal acts of 1379 cases. Based on these data, they show that areas with a high number of poor people are not followed by high crime and vice versa.

This happens because not all of criminals commit criminal acts motivated by economic factors. The positive flow says that criminal activity does not result from economic influence, but is caused by human behavior itself. Kathena dan Sheefeni (2013) said that a person tends to commit crimes due to environmental influences rather than internal influences, therefore controlling the outside influence can reduce the crime rate. Besides, the criminal data used in the study include all forms of crime reported to the local police, such as corruption, drugs, murder, rape, kidnapping, fraud, robbery, violence and others. So it can be concluded that not all criminals come from the poor because each individual does not act solely on the basis of habits and emotions but also considers the best alternative from the various options available according to the constraints and limitations they have. Everyone must have many desires, but not all desires can be achieved because a person's resources and ability to obtain something that is desired are limited.

Hebert A. Simon in Firmansyah et al., (2013) stated that the rationality of individual on making decisions is limited to information and cognitive abilities (habits, values, knowledge, references, etc.). So that a person's decision to participate in criminal activities is not a rational decision based on maximizing satisfaction. Hagan (2013) also stated that only some criminals are rational, the rest of them know very well what is being done.

This result is in line with study conducted by Dona dan Setiawan (2015) who found that the poor people has a negative and significant relationship to the crime rate in East 
Java Province. In line with this study, Prakoso (2016) also found that the poverty rate per province in the group of provinces with low income inequality in Indonesia in 2009-2013 has a negative and significant relationship to the crime rate in Indonesia.

\section{CONCLUSION}

The economic growth variable has a positive and insignificant relationship with the crime rate in East Java Province. This occurs as a result of income inequality among regions. The higher the socio-economic gap, the higher the crime rate in the region. The demographic variable, namely population density, has a positive and significant relationship with the crime rate in East Java Province. This occurs because of the increase in population results in the increase of competition among residents, one of which is in getting a job. When the workforce increases and is not followed by an increase in employment, it results in an increase of the unemployment rate, resulting in various kinds of criminal acts. The demographic variable, namely the number of poor people, has a negative and significant relationship with the crime rate in East Java Province. This happens because not all of criminals commit criminal acts motivated by economic factors, but tend to be influenced by the behavior of humans themselves and their surroundings or environments.

\section{REFERENCES}

Abdulsyani. (1987). Sosiologi Kriminalitas. Bandung: Remadja Karya CV Bandung. Adekoya, A. F., \& Razak, N. A. A. (2017). The Dynamic Relationship between Crime and Economic Growth in Nigeria. International Journal of Management and Economics, 53(1), 47-64. https://doi.org/10.1515/ijme-2017-0004

Ahmad, A., Ali, S., \& Ahmad, N. (2014). Crime and Economic Growth in Developing Countries: Evidence from Pakistan. J. Basic. Appl. Sci. Res, 4(4), 31-41.

Anata, F. (2013). Pengaruh Tingkat Pengangguran Terbuka, PDRB Perkapita, Jumlah Penduduk dan Index Williamson Terhadap Tingkat Kriminalitas (Studi Pada 31 Provinsi di Indonesia Tahun 2007-2012. Universitas Brawijaya.

Astutik, M. W. (2017). Ketimpangan Ekonomi Di Wilayah Tapal Kuda Povinsi Jawa Timur Tahun 2010 - 2014. Universitas Muhammaddiyah Malang.

Central Bureau of Statistics. (2014-2018). Statistik Kriminal Tahun 2014-2018. Jakarta: BPS

Central Bureau of Statistics. (2014-2019). Provinsi Jawa Timur Dalam Angka 2014-2019. Jawa Timur: BPS Jawa Timur.

Central Bureau of Statistics. (2019). PDRB Perkapita Atas Dasar Harga Konstan Kabupaten/Kota Di Jawa Timur 2013-2018. Jawa Timur: BPS Jawa Timur .

Central Bureau of Statistics. (2018). Perhitungan Angka Kemiskinan Maret 2018. Jakarta: BPS.

Becker, G. S. (1968). Crime and Punishment: An Economic Approach. Economic Analysis 
of the Law: Selected Readings, 76(2), 255-265. https://doi.org/10.1002/9780470752135.ch25

Becsi, Z. (1999). Economics and Crime in the States. Economic Review, (Q1), 38-56. Retrieved from http://ideas.repec.org/a/fip/fedaer/y1999iq1p38-56nv.84no.1.html

Beki, C., Zeelenberg, K., \& Montfort, K. Van. (1999). An Analysis of the Crime Rate in the Netherlands1950-1993. British Journal of Criminology, 39, 3.

Bender, K., \& Theodossiou, I. (2016). Economic Fluctuations and Crime: Temporary and Persistent Effects. Journal of Economic Studies, 43(4), 609-623. https://doi.org/10.1108/JES-05-2015-0085

Detotto, C., \& Otranto, E. (2010). Does crime affect economic growth? Kyklos, 63(3), 330-345. https://doi.org/10.1111/j.1467-6435.2010.00477.x

Dona, F. M., \& Setiawan. (2015). Pemodelan Faktor-Faktor Yang Mempengaruhi Tingkat Kriminalitas di Jawa Timur dengan Analisis Regresi Spasial. Jurnal Sains Dan Seni ITS, 4(1), 73-78. Retrieved from http://ejurnal.its.ac.id/index.php/sains_seni/article/view/8876/2228

Ekananda, M. (2015). Ekonometrika Dasar Untuk Penelitian Dibidang Ekonomi, Sosial dan Bisnis (Pertama). Jakarta: Mitra Wacana Media.

Firmansyah, M., Suman, A., \& Susilo, A. M. (2013). Rasionalitas Memilih Transaksi dengan Bank Syariah (Perspektif Teori Bounded Rationality). Proceeding Seminar Nasional Dan Call For Papers Sancall, 228-234.

Gujarati, D. N., \& Porter, D. C. (2013). Dasar-dasar Ekonometrika (Kelima; D. A. Halim, Ed.). Jakarta: Salemba Empat.

Hagan, F. E. (2013). Pengantar Kriminologi: Teori, Metode, dan Perilaku Kriminal Edisi Ketujuh. Jakarta: Kencana Prenada Media Group.

Kathena, I. N., \& Sheefeni, J. P. S. (2013). The Relationship Between Economic Growth and Crime Rates In Namibia. New Zealand Economic Papers, 47(2), 113-139. https://doi.org/10.1080/00779954.2013.776483

Khan, N., Ahmed, J., Nawaz, M., \& Zaman, K. (2015). The Socio-Economic Determinants of Crime in Pakistan: New Evidence on an Old Debate. Arab Economic and Business Journal, 10(2), 73-81. https://doi.org/10.1016/j.aebj.2015.01.001

Kusuma, H., Hariayani, H. F., \& Hidayat, W. (2019). The Relationship Between Crime and Economics Growth in Indonesia. KnE Social Sciences, 3(13), 1105. https://doi.org/10.18502/kss.v3i13.4271

Landa, J. T., \& Wang, X. T. (2002). Bounded Rationality of Economic Man : Decision Making under Ecological, Social, and Institutional Constraints. Journal of Bioeconomics, 217-236.

Laudrisen, J. ., Zeren, F., \& Ari, A. (2013). A Spatial Panal Data Analysis Of Crime Rates In EU. Discussion Papers on Business and Economics.

Lispani, N. M. L., Sumarjaya, I. W., \& Sukarsa, I. K. G. (2018). Pemodelan Jumlah Tindak Kriminalitas Di Provinsi Jawa Timur Dengan Analisis Regresi Spatial Autoregressive and Moving Average. E-Jurnal Matematika, 7(4), 346.

https://doi.org/10.24843/mtk.2018.v07.i04.p224 
Mulok, D., Lily, J., Kogid, M., \& Asid, R. (2016). The Relationship Between Crime and Economic Growth In Malaysia: Re-Examine Using Bound Test Approach. AIP Conference Proceedings, 1787(December), 24-25. https://doi.org/10.1063/1.4968159

Pavlo, L. (2011). Distribution Of Crime Across Ukraine : Panel and Spatial Analysis. 1-38.

Peri, G. (2004). Socio-cultural variables and economic success: Evidence from Italian provinces 1951-1991. Topics in Macroeconomics, 4(1). https://doi.org/10.2202/1534-5998.1218

Prakoso, D. B. (2016). Keterkaitan antara angka kriminalitas dengan variabel-variabel makroekonomi dan variabel demografi di indonesia. Institut Pertanian Bogor.

Salebu, J. B. (2018). Pengaruh PMA dan PDB Terhadap Penerimaan Pajak Indonesia: Analisis Data Panel 2005-2015. Simposium Nasional Keuangan Negara, 1, 603-627. https://doi.org/2549-8355

Supriono, A., Rondhi, M., \& Kusmiati, A. (2011). Penggandaan Basis Di Dalam Lingkup Perekonomian Regional Wilayah Tapal Kuda Dalam Periode Sebelum Maupun Setelah Pelaksanaan Otonomi Daerah. 5(2), 13-23. 